\title{
The Psychological Correlates of Dependency in the Jamaican Population
}

\author{
G Walcott ${ }^{1}$, FW Hickling ${ }^{2}$
}

\begin{abstract}
Objective: To establish the prevalence of psychological dependency in the Jamaican society in order to examine the relationship between the psychological correlates of dependency and socio-political dependency in this post-colonial country.

Methods: A total of 1506 adult individuals were sampled from 2150 households using a stratified sampling method and assessed using the 17 questions of the Jamaica Personality Disorder Inventory (JPDI) on the phenomenology of dependency that are grouped into the psychological features of physiological dependency, financial dependency, and psychological dependency. The database of responses to the demographic and JPDI questionnaires was created and analysed using the Statistical Package for the Social Sciences (SPSS) version 17.

Results: Of the national population sampled, $77.1 \%$ denied having any of these phenomenological symptoms of dependence while $22.63 \%$ of the population admitted to having some phenomenology of dependency, ranging from mild (5.6\%), to moderate (12.1), or severe (4.9\%). Substance use (physiological dependency) responders accounted for $21.23 \%$, financial dependency responders for $43.45 \%$, and psychological dependency responders for 15.96\%. Significant gender and socio-economic class patterns of dependency were revealed. This substantial swathe of the Jamaican population acknowledged their own dependency and behavioural withdrawal response to physical or emotional loss in their life, and reported having dependency problems in managing their financial and monetary affairs.

Conclusions: Three-quarters of the Jamaican responders of this survey ostensibly are free of the phenomenology of dependency while a more vulnerable one-quarter has insight that they are still locked in a struggle for psychological independence. The political and economic relations between psychological dependency and socio-political dependency are discussed.
\end{abstract}

Keywords: Dependency, Jamaican Personality Disorder Inventory, Jamaican population, phenomenology, personality disorder

\section{Correlatos Psicológicos de la Dependencia en la Población Jamaicana}

G Walcott ${ }^{1}$, FW Hickling ${ }^{2}$

\begin{abstract}
RESUMEN
Objetivo: Establecer la prevalencia de la dependencia psicológica en la sociedad jamaicana para examinar la relación entre los correlatos psicológicos de dependencia y la dependencia sociopolítica en este país postcolonial.

Métodos: Un total de 1506 individuos adultos fueron tomados como muestras a partir de 2150 hogares, usando un método de muestreo estratificado. Los individuos fueron posteriormente evaluados usando las 17 preguntas del Inventario de Trastornos de Personalidad en Jamaica (JPDI) sobre la fenomenología de la dependencia, las cuales se agrupan como características psicológicas de la dependencia fisiológica, dependencia económica y dependencia psicológica. La base de datos de respuestas a los cuestionarios de demografia y JPDI fue creada y analizada utilizando el Paquete Estadístico para la Ciencias Sociales (SPSS) versión 17.
\end{abstract}

From: ${ }^{1}$ South East Regional Health Authority, Kingston and St Andrew Public Health Service, 1 Marescaux Road, Kingston 5 and ${ }^{2}$ Caribbean Institute of Mental Health and Substance Abuse, The University of the West Indies, Kingston 7, Jamaica, West Indies.
Correspondence: Dr G Walcott, South East Regional Health Authority, Kingston and St Andrew Public Health Service, 1 Marescaux Road, Kingston 5, Jamaica. E-mail: dr.gwalcott@gmail.com 
Resultados: El 77.1\% de la población nacional muestreada negó tener ninguno de estos síntomas fenomenológicos de la dependencia, mientras que al 22.63\% de la población admitió tener una fenomenología de la dependencia, que fluctúa de valores leves (5.6\%) a moderados (12.1) o severos (4.9\%). Los encuestados del uso de sustancias (dependencia fisiológica) representaron el 21.23\%; los encuestados de dependencia financiera representaron el 43.45\%; y los encuestados de la dependencia psicológica fueron el $15.96 \%$. Se pusieron de manifiesto de forma significativa patrones de género y de clase socio-económica. Esta franja sustancial de la población jamaicana reconoció su propia dependencia y respuesta de aislamiento conductual ante la pérdida física o emocional en su vida, y reportó haber tenido problemas de dependencia en el manejo de sus asuntos financieros y monetarios. Conclusiones: Tres cuartas partes de los respondedores jamaicanos de esta encuesta aparentemente están libres de la fenomenología de la dependencia, mientras que una cuarta parte más vulnerable tiene la percepción de que aún están atrapados en una lucha por la independencia psicológica. Se discuten las relaciones políticas y económicas entre la dependencia psicológica y la dependencia sociopolítica.

Palabras claves: Dependencia, Inventario de Trastornos de la Personalidad en Jamaica, población Jamaicana, fenomenología, trastorno de la personalidad

West Indian Med J 2013; 62 (5): 412

\section{INTRODUCTION}

There has been much attention in recent years by the political scientists and lay press on the need for Jamaica to break 'the cycle of dependency' if it is to recover from the present economic downturn (1-3). The early scholars of dependency in Jamaica focussed primarily on the political and economic characteristics of dependency in Jamaica, but have neglected to examine the psychology of dependency and its relationship to the political science findings. Shifting the focus of dependency as an entirely socio-political phenomenon, the psychiatrists at The University of the West Indies have identified psychological dependency as one of the three phenomenological underpinnings of the psychopathology of personality disorder in Jamaica $(4,5)$. This led to the development of a 38-question screening instrument for personality disorder, the Jamaica Personality Disorder Inventory (JPDI) based on the phenomenological clinical triad of power management, dependency and sexual issues in patients with personality disorder (5) which in turn led to the study of the prevalence of personality disorder in a stratified sample of the Jamaican population (7). This present study centres on the responses of the stratified Jamaican population sample to the 17 questions that focussed on the phenomenology of psychological dependency. The objective of this study is to determine the prevalence of psychological dependency in the Jamaican society and to cull the relationship between the psychological correlates of dependency and features of socio-political dependency in this post-colonial country.

\section{SUBJECTS AND METHODS}

A total of 1506 adult individuals were sampled from 2150 households using a stratified sampling method to reflect the demographics of the general population. The survey was conducted by Market Research Services Limited (8), a Jamaican market research firm with almost 30 years of experience in conducting market research programmes in
Jamaica and across the Caribbean. A four-stage stratified random sampling method was used to identify the target population. The population was assessed using the Jamaica Personality Disorder Inventory (JPDI). The methodology is described elsewhere (7).

\section{Diagnostic measures}

Jamaica Personality Disorder Inventory (JPDI)

The JPDI is a 38-item interviewer administered questionnaire that was developed by The University of the West Indies, Section of Psychiatry, as a screening tool to identify the probability of being diagnosed with a personality disorder. Taking approximately 30 minutes for administration, the JPDI is intended to be linguistically simple and relevant to the reconceptualization of personality disorder. The JPDI has demonstrated reliability, and criterion-related and discriminant validity (6). The JPDI has 38 questions divided into three categories: dependency (questions 1 to 17), power management (questions 18 to 29) and psychosexual issues (questions 30 to 37). The JPDI's 17 questions on the phenomenology of dependency are grouped into the features of physiological dependency (1-7), financial dependency (8, 9 and 11), and psychological dependency $(10,12-17)$. The 17 questions are displayed in Table 1.

\section{Statistical analysis}

The database of responses to the demographic and JPDI questionnaires was created and analysed using the Statistical Package for the Social Sciences (SPSS) - version 17. Chisquared analysis was used to assess the differences in the prevalence rates of patients seen within a range of sociodemographic characteristics.

\section{RESULTS}

The total population sample for this study was 1506 persons with 727 males and 779 females. The sample was divided 
Table 1: The Jamaica Personality Disorder Inventory (JPDI) dependency questions and psychological correlates

\begin{tabular}{lll}
\hline No & JPDI items-Dependency & Category of dependency \\
\hline 1 & In the past month, have you used sleeping pills? & Physiological dependency \\
2 & In the past month, have you used pain-killing medications? & Physiological dependency \\
3 & In the past month, have you used alcohol? & Physiological dependency \\
4 & In the past month, have you used marijuana? & Physiological dependency \\
5 & In the past month, have you used cigarettes? & Physiological dependency \\
6 & In the past month, have you used cocaine? & Physiological dependency \\
7 & Have you been on regular prescription medication? & Physiological dependency \\
8 & Do you have regular money management problems? & Financial dependency \\
9 & Do you have a gambling problem? & Financial dependency \\
10 & Do you depend on people for emotional support? & Emotional dependency \\
11 & Do you depend on people for financial support? & Financial dependency \\
12 & If the person you depend on leaves you temporarily do you cry? & Psychological dependency \\
13 & If the person you depend on leaves you temporarily do you have temper tantrums? & Psychological dependency \\
14 & If the person you depend on leaves you temporarily do you destroy property? & Psychological dependency \\
15 & If the person you depend on leaves you temporarily do you behave violently towards others? & Psychological dependency \\
16 & If the person you depend on leaves you temporarily do you injure yourself? & Psychological dependency \\
17 & If the person you depend on leaves you temporarily would you attempt suicide? & Psychological dependency \\
\hline
\end{tabular}

into age groups with more than half the population being within the age range 25 to 44 years. There were 574 persons in relationships and 932 persons not in relationships. The persons were recruited from the fourteen parishes of Jamaica with 694 persons recruited from urban centres and 812 from rural areas. The persons were divided into three groups for socio-economical class (SEC) using the UK Registrar General's Classification by Occupation (9), SEC 1-3 (upper, middle and lower middle class), SEC 4 (skilled working class) and SEC 5 (working class and lowest level of subsistence). There were 155 persons in SEC $1-3$ and 387 in SEC 4 and the majority in SEC 5 (Table 2).

Table 2: Demographics

\begin{tabular}{rll}
\hline \multicolumn{2}{c}{ Demographic } & Number (\%) \\
\hline \multirow{2}{*}{ Gender } & Male & $727(48.3)$ \\
& Female & $779(51.7)$ \\
Relationship status & In relationship & $574(38.1)$ \\
& Not in relationship & $932(61.9)$ \\
& & \\
& $18-24$ & $281(18.7)$ \\
Age & $25-34$ & $399(26.5)$ \\
(year) & $45-54$ & $388(25.8)$ \\
& $55-64$ & $263(17.5)$ \\
& & $175(11.6)$ \\
Socio-economic status & SEC 1-3 & $155(10.3)$ \\
& SEC 4 & $387(25.7)$ \\
& SEC 5 & $964(64)$ \\
Location & Rural & $812(53.9)$ \\
& Urban & $694(46.1)$ \\
\hline
\end{tabular}

Cumulative responses (scores) to dependency questions With each question scoring yes (positive response, scoring 1 ), or no (negative response, scoring 0 ) the cumulative maximum negative responses were scored for the entire population and the total cumulative positive responses were scored for the questionnaire. An analysis of these scores revealed that $22.9 \%$ of the population admitted to having some phenomenology of psychological dependency. As the questionnaire allowed for people to answer on a Lickert scale of $0-5$ for severity, it was possible to categorize the number of positive responders with total cumulative scores ranging from mild $(5.6 \%)$, to moderate (12.1), or severe $(4.9 \%)$ [Table 3].

Table 3: Cumulative numbers of responders for all 17 Jamaica Personality Disorder Inventory dependency questions ranked for degree of severity

\begin{tabular}{lcc}
\hline & Total score & $\begin{array}{c}\text { Cumulative } \\
\text { percentage (\%) }\end{array}$ \\
\hline Never & 19713 & 77.36 \\
Minimum & 1427 & 5.6 \\
Moderate & 3101 & 12.16 \\
Severe & 1241 & 4.87 \\
\hline
\end{tabular}

This analysis also allowed for the delineation of $21.23 \%$ of the cohort admitting to having physiological (drug related) dependency issues, $43.45 \%$ admitting to having economic/financial dependency difficulties, and a further $15.96 \%$ admitting to experiencing personal psychological problems (Table 4).

Gender and socio-economic analysis of positive responders The positive responders to questions on physiological and psychological dependency were analysed for gender and socio-economic status using a Chi-square analysis. Males scored significantly higher for marijuana, cigarette and alcohol drug dependency than females $(p<0.05)$ while females scored significantly higher for the use of sleeping pills, pain killers and other prescribed medication. There were only four positive responders to the cocaine use question (one male and three females, $p>0.35$ ). Working class 
Table 4: Positive dependency responders

\begin{tabular}{lccc}
\hline & $\begin{array}{c}\text { Total positive } \\
\text { responders }\end{array}$ & $\begin{array}{c}\text { Total cohort } \\
\text { responders }\end{array}$ & \% \\
\hline $\begin{array}{l}\text { Substance abuse responders } \\
\text { (questions 1-7) }\end{array}$ & 2228 & 10542 & 21.23 \\
$\begin{array}{l}\text { Financial dependency } \\
\text { responders } \\
\text { (questions 8, 9, 11) }\end{array}$ & 1963 & 4518 & 43.45 \\
$\begin{array}{l}\text { Psychological dependency } \\
\text { responders } \\
\text { (questions 10, 12-17) }\end{array}$ & 1682 & 10542 & 15.96 \\
\hline
\end{tabular}

responders scored significantly higher than middle and upper class responders for marijuana and cigarette use $(p<0.03 s)$. Responders from all five socio-economic classes used alcohol and most prescribed medication in equal proportions $(p>$ 0.06) [Table 5].

\section{Financial dependency}

Females scored significantly higher for money management and financial dependency issues $(p<0.001)$, while males scored significantly higher on the admission of having a gambling problem. Working class persons (SEC 4 and 5) admitted to significantly greater financial dependency, money management and gambling issues than middle and upper middle class responders $(p<0.01)$ [Table 6].

\section{Physiological dependency}

Female responders admitted to being significantly more prone to needing emotional support and to exhibiting tearful behaviour when experiencing a sense of loss than the male responders $(p<0.000)$, whereas there was no significant gender difference with regards to throwing temper tantrums, destroying property, being violent toward others or self when experiencing a sense of loss $(p>0.07)$. Upper and middle class responders reported greater need of emotional support and to exhibiting tearful behaviour when experiencing a sense of loss than working class responders $(p<0.03)$. Although working class responders reported being significantly more likely to respond with violence after experiencing a sense of loss than upper and middle class responders, there were no significant differences in the display of temper tantrums or self-inflicted injury between the social class groupings $(p>0.11)$ [Table 7].

Table 5: Positive responders by gender and socio-economic status for substance dependency

\begin{tabular}{|c|c|c|c|c|c|c|c|}
\hline \multirow{2}{*}{$\begin{array}{l}\text { Substance } \\
\text { dependence } \\
\text { question number }\end{array}$} & \multirow[b]{2}{*}{$\begin{array}{c}\text { Male }=727 \\
\text { n (\%) }\end{array}$} & \multicolumn{2}{|l|}{ Gender } & \multicolumn{4}{|c|}{ Social status } \\
\hline & & $\begin{array}{c}\text { Female }=779 \\
\text { n }(\%)\end{array}$ & $p$-value & $\begin{array}{l}\text { SEC 1-3 } \\
\quad=155\end{array}$ & $\begin{array}{l}\text { SEC } 4 \\
=\mathbf{3 8 7} \\
\text { n (\%) }\end{array}$ & $\begin{array}{l}\text { SEC } 5 \\
=964 \\
\text { n }(\%)\end{array}$ & $\begin{array}{l}p \text {-value } \\
\text { n (\%) }\end{array}$ \\
\hline 1. Sleeping pills & $22(3.0)$ & $34(4.4)$ & $0.031 \mathrm{~s}$ & $9(5.8)$ & $11(2.8)$ & $36(3.7)$ & $0.21 \mathrm{~ns}$ \\
\hline 2. Pain killer & $212(29.0)$ & $372(47.8)$ & $0.000 \mathrm{vs}$ & $70(45.1)$ & $150(38.9)$ & $364(37.7)$ & $0.06 \mathrm{~ns}$ \\
\hline 3. Alcohol & $473(65.1)$ & $187(24.0)$ & $0.000 \mathrm{vs}$ & $70(45.1)$ & $165(42.6)$ & $425(44.0)$ & $0.08 \mathrm{~ns}$ \\
\hline 4. Marijuana & $211(29.0)$ & $24(3.1)$ & $0.000 \mathrm{vs}$ & $5(3.2)$ & $52(13.4)$ & $178(18.5)$ & $0.000 \mathrm{vs}$ \\
\hline 5. Cigarettes & $185(25.5)$ & $51(6.6)$ & $0.000 \mathrm{vs}$ & $10(6.5)$ & 57 (14.7) & $169(17.5)$ & $0.03 \mathrm{~s}$ \\
\hline 6. Cocaine & $1(0.1)$ & $3(0.4)$ & $0.39 \mathrm{~ns}$ & $1(0.6)$ & $2(0.5)$ & $1(0.1)$ & $0.06 \mathrm{~ns}$ \\
\hline 7. Prescribed drugs & $161(22.2)$ & $292(37.5)$ & $0.000 \mathrm{vs}$ & $52(33.5)$ & $119(30.8)$ & $282(29.4)$ & $0.37 \mathrm{~ns}$ \\
\hline Total & 1265 & 963 & & 217 & 556 & 1455 & $=2228$ \\
\hline
\end{tabular}

Table 6: Positive responders by gender and socio-economic status for financial dependency

\begin{tabular}{|c|c|c|c|c|c|c|c|}
\hline \multirow{2}{*}{$\begin{array}{l}\text { Financial } \\
\text { dependency } \\
\text { question number }\end{array}$} & \multirow[b]{2}{*}{$\begin{array}{c}\text { Male }=727 \\
\text { n (\%) }\end{array}$} & \multirow{2}{*}{$\begin{array}{c}\text { Gender } \\
\begin{array}{c}\text { Female }=779 \\
\text { n }(\%)\end{array}\end{array}$} & \multirow[b]{2}{*}{$p$-value } & \multicolumn{3}{|c|}{ Social status } & \multirow[b]{2}{*}{ p-value } \\
\hline & & & & $\begin{array}{l}\text { SEC 1-3 } \\
\quad=155 \\
\text { n }(\%)\end{array}$ & $\begin{array}{l}\text { SEC } 4 \\
=387 \\
\text { n (\%) }\end{array}$ & $\begin{array}{c}\text { SEC } 5 \\
=964 \\
(\%)\end{array}$ & \\
\hline 8. Money problems & $430(59.1)$ & $502(64.4)$ & $0.001 \mathrm{vs}$ & $81(52.3)$ & $213(55.0)$ & $638(66.2)$ & $0.000 \mathrm{vs}$ \\
\hline 9. Gambling & $182(25.0)$ & $100(12.8)$ & $0.001 \mathrm{vs}$ & $27(17.4)$ & $77(19.9)$ & $178(18.5)$ & $0.01 \mathrm{~s}$ \\
\hline 11. Financial support & $272(37.4)$ & 477 (61.2) & $0.000 \mathrm{vs}$ & $72(46.5)$ & $183(47.3)$ & $494(51.3)$ & $0.001 \mathrm{vs}$ \\
\hline Total & 884 & 1079 & & 180 & 473 & 1310 & $=1963$ \\
\hline
\end{tabular}


Table 7: Positive responders by gender and socio-economic status for psychological dependency

\begin{tabular}{|c|c|c|c|c|c|c|c|}
\hline \multirow{2}{*}{$\begin{array}{l}\text { Psychological } \\
\text { dependency } \\
\text { question number }\end{array}$} & \multirow[b]{2}{*}{$\begin{array}{c}\text { Male }=727 \\
\text { n (\%) }\end{array}$} & \multicolumn{2}{|l|}{ Gender } & \multicolumn{3}{|c|}{ Social status } & \multirow[b]{2}{*}{ p-value } \\
\hline & & $\begin{array}{c}\text { Female }=779 \\
\text { n (\%) }\end{array}$ & $p$-value & $\begin{array}{c}\text { SEC 1-3 } \\
=155 \\
\text { n }(\%)\end{array}$ & $\begin{array}{l}\text { SEC } 4 \\
=387 \\
\text { n (\%) }\end{array}$ & $\begin{array}{c}\text { SEC } 5 \\
=964 \\
(\%)\end{array}$ & \\
\hline 10. Emotional support & $295(40.6)$ & $430(55.2)$ & $0.000 \mathrm{vs}$ & $85(54.8)$ & $180(46.5)$ & $460(47.7)$ & $0.03 \mathrm{~s}$ \\
\hline 12. Cry & $170(23.4)$ & $318(40.8)$ & $0.000 \mathrm{vs}$ & $37(23.9)$ & $126(32.6)$ & $325(33.7)$ & $0.01 \mathrm{~s}$ \\
\hline 13. Temper tantrum & $131(18.0)$ & $150(19.3)$ & $0.07 \mathrm{~ns}$ & $17(11.0)$ & 76 (19.6) & $188(19.5)$ & $0.16 \mathrm{~ns}$ \\
\hline 14. Destroy property & $20(2.8)$ & $31(4.0)$ & $0.56 \mathrm{~ns}$ & $2(1.3)$ & $15(3.9)$ & $34(3.5)$ & $0.16 \mathrm{~ns}$ \\
\hline 15. Violent toward others & $36(5.0)$ & $50(6.4)$ & $0.18 \mathrm{~ns}$ & $3(1.9)$ & $38(9.8)$ & $45(4.7)$ & $0.004 \mathrm{vs}$ \\
\hline 16. Injure self & $10(1.4)$ & $13(1.7)$ & $0.51 \mathrm{~ns}$ & $1(0.6)$ & $8(2.1)$ & $14(1.5)$ & $0.48 \mathrm{~ns}$ \\
\hline 17. Attempt suicide & $13(1.8)$ & $15(1.9)$ & $0.89 \mathrm{~ns}$ & $1(0.7)$ & $10(2.6)$ & $17(1.8)$ & $0.11 \mathrm{~ns}$ \\
\hline Total & 675 & 1007 & & 146 & 453 & 1083 & $=1682$ \\
\hline
\end{tabular}

\section{DISCUSSION}

The definition of dependency as a state in which one relies on others for the basic necessities of life was expanded by Gurian and Gurian to include seeking a sense of identity, support, security and permission outside of oneself (11). This study departs from the primarily socio-political analytic direction of the political economists in the Caribbean who have studied the phenomenon of dependency in recent decades by attempting to examine a priori, the psychological state of dependency in the minds of Jamaican people. This research indicates that nearly $23 \%$ of the Jamaican population admits to having thoughts, feelings and behaviours that reflect dependency issues of varying severity. The questions framed in the JPDI used in this study originated from a study of the phenomenological symptoms of personality disorder in Jamaican patients (4-6). The questions were framed by focus groups of psychiatrists and psychologists at The University of the West Indies (6) and reflected the clinical findings of patients in Jamaica, and attempted to capture the symptoms of dependency based on physiological habits (licit or illicit drug use), money management and financial addictions, and/or psychological cravings captured in the questions as a response to withdrawal or loss. An important finding of this study is that over $77 \%$ of the national population sampled denied having any of these phenomenological symptoms of dependence. However, of the $23 \%$ of Jamaicans who affirmed having these phenomena, significant gender and socio-economic class patterns were revealed. Females scored significantly higher for the use of sleeping pills, painkillers and other prescribed medication than men, and scored significantly higher for the exhibition of money management and financial dependency problems. Female responders also admitted to being significantly more prone to needing emotional support and to exhibiting tearful behaviour when experiencing a sense of loss than the male responders. Males on the other hand scored significantly higher for marijuana, cigarette and alcohol drug use than females, and scored significantly higher for the admission of having a problem with gambling. There was no significant gender difference with regard to the throwing of temper tantrums, destroying property, being violent toward others or self when experiencing a sense of loss or being thwarted.

Working class (SEC 4 and 5) responders scored significantly higher that middle and upper class responders for marijuana and cigarette use, whereas responders from all five socio-economic classes used alcohol and prescribed medication equally. Working class persons admitted to financial dependency, money management and gambling issues than middle and upper middle class responders (SEC 1-3). Upper and middle class responders reported greater need of emotional support and to exhibiting tearful behaviour when experiencing a sense of loss than working class responders, but working class responders reported being significantly more likely to respond with violence after experiencing a sense of loss than upper and middle class responders. There were no significant differences in the display of temper tantrums or self-inflicted injury between the social class groupings.

The interpretation of these findings suggests that the self-admission of this cohort of Jamaicans revealed that nearly one quarter of this random stratified population sample identify elements of unfulfilled dependency needs in themselves. The fact that many of these dependency needs are focussed on drugs that are used to reduce existing symptoms of anxiety and pain is also revealing. That this substantial swathe of the Jamaican population acknowledged their own withdrawal response to physical or emotional loss in their life points to deep-seated feelings of inadequacy in the minds of these Jamaican people. They reported problems in managing financial and monetary affairs, and the open economic dependence on others suggest a major vulnerability for economic exploitation and extortion by unscrupulous manipulators.

Jamaican political economist George Beckford has recognized that "...the most intractable problem is the colonized condition of the minds of the people. Until we decolonize the mind, there is little hope that genuine independence can be achieved..." (1). Beckford's seminal polemic on the psycho-social under-developing influence of 
the European plantation economy created in the $15^{\text {th }}$ century reminds us that the Jamaican people have been coping with the institutional problems of dependency for centuries, and remains the central authority to underline the profound link between psychological dependency and socio-economic dependency. "...This psychological dependence is a phenomenon that has persisted, and continues to be...the chief obstacle to change and transformation in plantation economies..." (1). Our present study encourages us to observe the reality of dependency from the obverse, namely, by looking at the elements of psychological dependency in the minds of contemporary Jamaican people, we can examine the dynamics of this phenomenon that has persisted from slavery; how it feeds off emotions of anxiety and hopelessness, which in turn catalyses inappropriate social behaviour and action such as drug use and abuse, financial mismanagement and violent aggression. The results suggest that this aggression is rarely turned inwards toward self as a suicidal behaviour, but much more commonly is externalized to other individuals in the society. The deep-seated dependency problems unearthed by this study, suggesting that nearly $10 \%$ of the population cohort report that they behave violently toward others if they feel thwarted or experience a sense of loss, is an expression of the transgressive behaviour of a relatively small but significant number of Jamaican people. The recent reports of domestic violence resulting in gruesome murder/suicides occurring in Jamaica as a reaction to personal emotional loss in the local newspapers (10), is cited as an example of this deep-seated psychological dependency revealed by this Jamaican population study. But perhaps the most important conclusion to be drawn from the gestalt of these findings concerns the ongoing struggle that is taking place contemporaneously in the Jamaican population for psychological independence. The majority (threequarters) of the responders of this survey who report no dependency symptoms seemingly have freed themselves from the ravages of dependency while a more vulnerable one-quarter who admit to having dependency phenomenology have insight that they are still locked in the struggle to rid their minds and their lives of this crippling remnant of the historical plantation economy.

\section{REFERENCES}

1. Beckford G. Persistent poverty: underdevelopment in plantation economies of the third world. Kingston, Jamaica: the UWI Press; 1972.

2. Rose EA. Dependency and socialism in the modern Caribbean: Guyana, Jamaica and Granada, 1970-1985. New York: Lexington Books; 2002.

3. "Jamaica needs to break the cycle of dependency". The Gleaner. 2009 March 30: Business.

4. Hickling FW, Martin J, Harrisingh-Dewar A. Redefining personality disorder in Jamaica. In: Hickling FW, Matthies BK, Morgan K, Gibson RC, eds. Perspectives in Caribbean psychology. Kingston, Jamaica: CARIMENSA, The University of the West Indies; 2008; 263-88.

5. Hickling FW, Paisley V. Redefining personality disorder: a Jamaican perspective. Rev Panam Salud Publica 2011; 30: 255-61.

6. Hickling FW, Walcott G, Martin J. The creation and validation of the Jamaica Personality Disorder Inventory. West Indian Med J 2013; 62: 389-96.

7. Hickling FW, Walcott G. Prevalence and correlates of personality disorder in the Jamaican population. West Indian Med J 2013; 62: 443 7.

8. Market Research Services Limited (MRSL) [homepage on the Internet]. Kingston, Jamaica: Market Research Services Limited [cited 2011 Aug 31]. Available from: http://www.mrsl.com.jm/

9. Rose D. Official social classifications in the UK [Internet]. Soc Res Update 1995; 9: 1-7. [cited 9 December 2009]. Available from: http:// sru.soc.surrey.ac.uk/SRU9. html

10. Titus M. 'Killer dad was seen as model father'. The Gleaner. 2013 Feb 27: News.

11. Gurian JP, Gurian JM. The dependency tendency: returning to each other in modern America. University Press of America; 1983. 